\title{
PROBLEMATIKA PENGUNGKAPAN RAHASIA BANK ANTARA KEPENTINGAN NEGARA DAN PERLINDUNGAN KEPADA NASABAH
}

\author{
Rizky Fahrurrozi ${ }^{1}$, \\ 1 Program Doktor Ilmu Hukum Universitas Padjadjaran Bandung, \\ Email : fahurrozi.rizky@gmail.com \\ Tarsisius Murwadji ${ }^{2}$ \\ 2 Ketua Promotor, Guru Besar Ilmu Hukum Fakultas Hukum Universitas Padjadjaran Bandung \\ Mien Rukmini ${ }^{3}$ \\ ${ }^{3}$ Anggota Promotor I, Guru Besar Ilmu Hukum Fakultas Hukum Universitas Padjadjaran \\ Bandung
}

\begin{abstract}
The objectives of this researh are to analyze (1) the implementation bank secrecy as a form of legal protection to customers; (2) problematic disclosure of bank secrecy between state interests and protection to customers; (3) bank refusal rights to open bank secrecy. The method used is the normative legal research with statute and conceptual approaches. The research result indicated (1) the implementation bank secrecy as a form of legal protection to customers consists of preventive and repressive legal protection; (2) The problematic disclosure of bank secrecy between state interests and protection to customers must be done in a balanced manner so that public opinion does not arise that seems as though bank secrets are no longer relevant and (3) bank refusal rights to open bank secrecy indicates that the bank has the right to refuse to open bank secrets based on the contractual relationship between the bank and its customers. According to Article 1338 of the Civil Code the agreement is binding on the parties who make it, but it is not binding on third parties in this case including the state as a third party.
\end{abstract}

Keywords: Bank Secrecy, Disclosure, State Interest, Customer Protection.

\begin{abstract}
Abstrak
Tujuan penelitian ini untuk menganalisis (1) penerapan rahasia bank sebagai bentuk perlindungan hukum kepada nasabah; (2) problematika pengungkapan rahasia bank antara kepentingan negara dan perlindungan kepada nasabah;dan (3) hak tolak bank untuk membuka rahasia bank. Metode penelitian yang digunakan adalah penelitian hukum yuridis normatif dengan menggunakan pendekatan perundang-undangan dan konseptual. Hasil penelitian menunjukkan (1) Penerapan rahasia bank sebagai bentuk perlindungan hukum kepada nasabah terdiri dari perlindungan hukum preventif dan represif; (2) Problematika pengungkapan rahasia bank antara kepentingan negara dan perlindungan kepada nasabah harus dilakukan secara seimbang agar tidak timbul opini publik bahwa seolah-olah rahasia bank sudah tidak relevan lagi keberadaannya dan (3) Hak tolak bank untuk membuka rahasia bank menunjukkan bahwa bank berhak menolak untuk membuka rahasia bank berdasarkan hubungan kontraktual antara bank dengan nasabahnya. Menurut Pasal 1338 KUHPerdata perjanjian mengikat bagi para pihak yang membuatnya, tetapi tidak mengikat bagi pihak ketiga dalam hal ini termasuk negara sebagai pihak ketiga.
\end{abstract}

Kata Kunci: Rahasia Bank, Pengungkapan, Kepentingan Negara, Perlindungan Nasabah. 


\section{Pendahuluan}

Industri perbankan merupakan salah satu komponen yang sangat menentukan dalam perekonomian nasional demi menjaga keseimbangan, kemajuan dan kesatuan ekonomi nasional. Bank pada dasarnya mempunyai fungsi menghimpun dana dari masyarakat atau dari nasabah penyimpan dan mentransfer kepada nasabah debitur yang membutuhkan. Bank sebagai lembaga utama di bidang keuangan diharapkan dapat menjaga kepercayaan masyarakat atas simpanan yang yang ditanamkan kepadanya. Masyarakat yang tidak percaya lagi terhadap suatu bank, maka yang bersangkutan akan menarik dananya di bank tersebut dengan seketika. Apalagi hal yang sama juga dilakukan oleh nasabah lainnya, maka akan terjadi "bank rush". Tak ada satu bankpun yang bisa menghadapi "bank rush" itu. Untuk mempertahankan kepercayaan masyarakat, bank wajib menjaga rahasia bank mengingat masyarakat menjadi merasa aman apabila rahasia dana simpanannya dijamin kerahasiaannya oleh bank. Rahasia bank merupakan salah satu pilar utama kepercayaan masyarakat yang wajib dijaga bank secara terus menerus. Pilar-pilar kepercayaan yang lainnya adalah kehati-hatian, kesehatan, dan kepastian. ${ }^{1}$

Pengertian rahasia bank mengacu kepada rahasia dalam hubungan antara bank dengan nasabahnya. Sedangkan rahasia-rahasia lain yang bukan merupakan rahasia antara bank dengan nasabah, sungguhpun juga bersifat "rahasia" tidak tergolong ke dalam istilah "rahasia bank". Menurut Munir Fuady, "hubungan antar bank dengan nasabahanya tidaklah hubungan kontraktual biasa, namun dalam hubungan tersebut terdapat kewajiban bagi bank untuk tidak membuka rahasia dari nasabahnya kepada pihak lain manapun kecuali jika ditentukan lain oleh perundang-undangan yang berlaku".2

Rahasia bank (bank secrecy, financial privacy) dianggap sebagai hak asasi manusia yang harus dilindungi dari campur tangan negara dan orang lain. Adanya ketentuan rahasia bank ditujukan untuk kepentingan nasabah agar terlindungi kerahasiaan yang menyangkut keadaan keuangannya dan juga bagi kepentingan bank itu sendiri agar bank dapat dipercaya dan kelangsungan hidupnya terjaga. ${ }^{3}$ Rahasia bank di Indonesia, diatur di dalam Pasal 40 Undang-Undang Nomor 10 Tahun 1998 tentang Perubahan Atas Undang-Undang Nomor 7 Tahun 1992 tentang Perbankan (selanjutnya disebut UU Perbankan) yang menyatakan:

"Bank wajib merahasiakan keterangan mengenai nasabah penyimpan dan simpanannya, kecuali dalam hal sebagaimana dimaksud dalam Pasal 41, Pasal 41 A, Pasal 42, Pasal 43, Pasal 44 dan Pasal 44 A. “

Berdasarkan ketentuan tersebut maka dapat dilihat bahwa bank di Indonesia wajib menerapkan rahasia bank, dimana rahasia bank yang diterapkan sebatas dan terbatas pada keterangan mengenai nasabah penyimpan dan simpanannya, sehingga

${ }^{1}$ Tarsisius Murwadji, Antisipasi Pelarian Dana Asing ke Luar Negeri Melalui Perlindungan Kontraktual Pembukaan Rahasia Bank, Padjadjaran Jurnal Ilmu Hukum, Vol. 2, No. 2, 2015, Hlm. 233.

2 Munir Fuady, Hukum Perbankan Modern, Edisi Revisi, PT. Citra Aditya Bakti, Bandung, 2009, Hlm. 89.

3 Yunus Husein, Rahasia Bank dan Penegakan Hukum, Pustaka Juanda Tigalima, Jakarta, 2010, Hlm. 133-145. 
keterangan selain terkait dengan nasabah penyimpan dan simpanannya bukan merupakan rahasia bank, misalnya keterangan mengenai debitur dan pinjamannya. ${ }^{4}$

Ketentuan rahasia bank antara lain ditujukan untuk kepentingan nasabah agar kerahasiaannya terlindungi. Kerahasiaan tersebut menyangkut keadaan keuangannya. Selain itu juga, ketentuan rahasia bank diperuntukkan juga bagi kepentingan bank, agar dapat dipercaya dan kelangsungan hidupnya terjaga. ${ }^{5}$ Pengaturan mengenai rahasia bank berbeda dari satu negara dengan negara lainnya. Swiss merupakan negara yang mengatur rahasia bank dengan ketat. Oleh karena itu banyak orang yang lebih memilih Swiss untuk menyimpan uangnya karena terjamin dan terjaga rahasia dan data-data dirinya. ${ }^{6}$

Prinsip bank secrecy (rahasia bank) pada awalnya dalam rangka pengembangan usaha di kalangan perbankan sendiri yang membutuhkan kepercayaan publik agar mau menyimpan dana atau uangnya. Pada perbankan, publik bersedia menyimpan uang atau dananya di bank dan/atau bersedia melakukan transaksi dengan bank jika pihak bank menjamin bahwa data mengenai keuangan/simpanan dan kondisi uang nasabah dirahasiakan dan tidak disalah-gunakan. Berdasarkan argumentasi ini, sudah seharusnya pihak bank berpegang teguh pada prinsip kerahasiaan bank. Jika simpanan/dana nasabah mendapat jaminan kerahasiaannya, maka dapat memperkuat rasa percaya publik atas bank yang telah dipilih dan oleh karenanya bisa berdampak pada pertambahan jumlah nasabah pada bank itu sendiri.

Prinsip bank secrecy atau kerahasiaan bank sudah menjadi kebiasaan di kalangan perbankan mengingat dunia perbankan mempunyai aktivitas bisnis yang berlainan dengan dunia perdagangan. Perbankan melaksanakan aktivitas bisnis berlandaskan kepercayaan publik dan berdasarkan rasa percaya itu publik bersedia menyimpan uangnya di bank serta bersedia memanfaatkan jasa dunia perbankan. Rasa percaya publik atas dunia perbankan muncul karena dunia perbankan bisa menjamin rahasia nasabah serta kerahasiaan simpanannya yang biasa dilakukan kalangan perbankan terhadap nasabahnya berdasarkan customer law. Kebiasaan itu, jika pada perjanjian bank dengan nasabah tidak tercantum ada kewajiban dari bank agar merahasiakan atau disebut dengan istilah "duty of confidentiality", maka kewajiban tersebut dipandang telah ada secara tersirat dan oleh karenanya pihak bank tetap wajib menjaga kerahasiaan informasi nasabah serta berlaku juga untuk mantan nasabah.

Ketentuan mengenai rahasia bank di Indonesia menjadi suatu problematika, khususnya bila dikaitkan dengan kepentingan negara. Di satu sisi bank yang harus menjaga kepercayaan masyarakat mempunyai tugas sepatutnya dan seharusnya melindungi serta merahasiakan terkait dengan data nasabah dan simpanannya apabila nasabah tersebut jujur dan bersih. Namun disisi lain, bank juga berkewajiban mendukung kepentingan negara apabila data nasabah tersebut diperlukan oleh Negara

4 John Bert Christian, Bismar Nasution dan Suhaidi, Mahmul Siregar, Analisis Hukum Atas Penerapan Rahasia Bank di Indonesia Terkait dengan Perlindungan Data Nasabah Berdasarkan Prinsip Kepercayaan Kepada Bank, USU Law Journal, Vol.4, No.4, 2016, Hlm.132.

5 Gabriel C. Singson, Law and Jurisprudence on Secrecy of Bank Deposits, Ateneo Law Journal, Vol. 46, 2001, Hlm. 673.

${ }^{6}$ Tumpak Hasiholan Manurung, Maryati Bachtiar dan Dasrol, Analisis Yuridis Mengenai Bentuk Perlindungan Rahasia Bank dan Sanksi terhadap Pelanggaran Rahasia Bank, JOM Fakultas Hukum, Volume II, Nomor 2, 2015, Hlm. 2. 
untuk mengungkap adanya pelanggaran dan/atau kejahatan/tindak pidana terhadap Negara.

Pasal 40 UU Perbankan menegaskan bahwa bank wajib merahasiakan keterangan mengenai nasabah penyimpan dan simpanannya. Pada sisi lain, dalam Pasal 40 UU Perbankan juga ditegaskan mengenai pengecualian kewajiban merahasiakan untuk kepentingan negara sebagaimana diatur dalam Pasal 41 UU Perbankan (untuk kepentingan perpajakan), Pasal 41A UU Perbankan (penyelesaian piutang bank yang sudah diserahkan kepada Badan Urusan Piutang dan Lelang Negara), Pasal 42 UU Perbankan (kepentingan peradilan dalam perkara pidana), Pasal 43 UU Perbankan (perkara perdata bank dengan nasabah), Pasal 44 UU Perbankan (tukar-menukar informasi antar bank), dan Pasal 44A UU Perbankan (bank wajib memberikan keterangan kepada kuasa Nasabah Penyimpan). Ketentuan-ketentuan tersebut di atas merupakan das sollen bagi pengaturan terkait rahasia bank dengan pengecualian dapat diungkapkan bila menyangkut kepentingan negara. Namun pada kenyataannya (das sein) bank juga seringkali mengungkapkan data nasabah yang merupakan rahasia bank selain untuk kepentingan negara seperti misalnya untuk kepentingan pemasaran produk-produknya seperti kartu kredit, kredit tanpa agunan, asuransi yang dikelola oleh bank yang bersangkutan dan sebagainya. Berdasarkan gap/kesenjangan antara das sollen dengan das sein tersebut, maka penelitian ini bermaksud untuk membahas problematika pengungkapan rahasia bank antara kepentingan negara dan perlindungan kepada nasabah.

Rumusan masalah dalam penelitian ini sebagai berikut: pertama, bagaimana penerapan rahasia bank sebagai bentuk perlindungan hukum kepada nasabah? kedua, bagaimana problematika pengungkapan rahasia bank antara kepentingan negara dan perlindungan kepada nasabah? dan ketiga, bagaimana hak tolak bank untuk membuka rahasia bank?.

\section{Metode Penelitian}

Penelitian ini adalah penelitian hukum normatif dengan pendekatan statute approach (pendekatan perundang-undangan) dan conceptual approach (pendekatan konseptual). Mengingat jenis penelitian ini berpangkal pada penelitian normatif, maka sebagian besar data dan bahan-bahan hukum yang digunakan mengacu pada data sekunder yang mencakup bahan-bahan hukum primer, terdiri dari berbagai peraturan perundang-undangan, jurisprudensi, dan konvensi-konvesni yang terkait dengan pengungkapan rahasia bank untuk kepentingan peradilan dalam tindak pidana perbankan, serta bahan hukum sekunder dan tersier. ${ }^{7}$ Penelitian ini juga menggunakan data primer, yaitu data yang diperoleh langsung dari responden atau narasumber yang terkait dengan problematika pengungkapan rahasia bank antara kepentingan negara dan perlindungan kepada nasabah.

Dalam pengumpulan data, peneliti melakukan penelusuran literature (library research), baik secara ekstensif maupun intensif. Penelitian kepustakaan bertujuan untuk

7 Ronny Hanitijo Soemitro, Metode Penelitian Hukum dan Jurumetri, Ghalia Indonesia, Jakarta, 2010, Hlm. 97. 
mengkaji, meneliti, dan menelusuri data sekunder, berupa bahan-bahan hukum. ${ }^{8}$ Bahan-bahan hukum bersifat normatif-prespektif, digunakan terutama untuk mengkaji permasalahan hukum yang terkait dengan substansi peraturan hukum positifnya (ius constitutum) yang sifatnya mengatur tentang problematika pengungkapan rahasia bank antara kepentingan negara dan perlindungan kepada nasabah, berdasarkan kekuatan mengikatnya diklasifikasikan sebagai bahan hukum primer, bahan hukum sekunder dan bahan hukum tersier. ${ }^{9}$ Teknik analisis data yang digunakan merupakan analisis yuridis yaitu analisis yang mendasarkan pada teori-teori, konsep dan peraturan perundang-undangan.

\section{Hasil Penelitian dan Pembahasan}

\subsection{Penerapan Rahasia Bank sebagai Bentuk Perlindungan Hukum Kepada Nasabah}

Ketentuan rahasia bank antara lain ditujukan untuk kepentingan nasabahagar kerahasiaannya terlindungi. Kerahasiaan tersebut menyangkut keadaan keuangannya. Selain itu juga, ketentuan rahasia bank diperuntukkan juga bagi kepentingan bank, agar dapat dipercaya dan kelangsungan hidupnya terjaga. Di Indonesia, pengaturan rahasia bank lebih dititikberatkan pada alasan untuk kepentingan bank, seperti terlihat dalam penjelasan Pasal 40 UU Perbankan yang menyebutkan bahwa kerahasiaan ini diperlukan untuk kepentingan bank itu sendiri yang memerlukan kepercayaan masyarakat yang menyimpan uangnya di bank.Ada lima alasan yang mendasari kewajiban bank untuk merahasiakan segalasesuatu tentang nasabah dan simpanannya, yaitu:

a. "Personal Privacy

b. Hak yang timbul dari hubungan perikatan antara bank dan nasabah

c. Peraturan perundang-undangan yang berlaku

d. Kebiasaan atau kelaziman dalam dunia perbankan

e. Karakteristik kegiatan usaha bank sebagai suatu "lembaga kepercayaan" yang harus memegang teguh kepercayaan nasabah yang menyimpan uangnya di bank.10"

Hubungan hukum antara nasabah penyimpan dan bank didasarkan atas suatu perjanjian. Untuk itu adalah wajar apabila kepentingan dari nasabah yang bersangkutan mendapat perlindungan hukum, sebagaimana perlindungan yang diberikan oleh hukum kepada bank. Telah ada political will dari pemerintah untuk melindungi kepentingan nasabah bank penyimpan dan simpanannya, hal ini diatur dalam Pasal 1 Angka 28, 40, 47 dan 47A UU Perbankan. ${ }^{11}$

Penerapan rahasia bank sebagai bentuk perlindungan hukum kepada nasabah dibedakan menjadi 2 (dua) yaitu perlindungan hukum preventif dan perlindungan hukum represif yang diuraikan sebagai berikut:

${ }^{8}$ Bambang Waluyo, Penelitian Hukum Dalam Praktik, Penerbit Sinar Grafika, Jakarta, 2011, Hlm. 18.

9 Soerjono Soekanto, Pengantar Penelitian Hukum, Universitas Indonesia Press, Jakarta, 2012, Hlm. 52.

${ }^{10}$ Ibid., Hlm. 146-147.

${ }^{11}$ Hendrik Agus Sutiawan, Etty Mulyati dan Ijud Tajudin, Perlindungan Nasabah Terkait Praktik Pembukaan Rahasia Bank oleh Pegawai Bank dalam Proses Penegakan Hukum Tindak Pidana Pencucian Uang Dihubungkan dengan Asas Kepastian Hukum, Jurnal Hukum \& Pembangunan, Vol. 48, No.3, 2018, Hlm.633. 


\section{a. Perlindungan Hukum Preventif}

Internal bank secara tidak langsung memberikan perlindungan hukum kepada nasabah terhadap segala resiko kerugian yang timbul dari kegiatan usaha bank yang berkaitan dengan prinsip kehati-hatian, terutama dalam hal penggunaan data pribadi nasabah. Perlindungan hukum preventif yang dilakukan oleh bank berkaitan dengan data pribadi nasabah ini tentunya harus sesuai dengan peraturan yang berlaku. Peraturan khusus yang berkaitan dengan ini antara lain Pasal 9-11 Peraturan Bank Indonesia Nomor 7/6/PBI/2005 tentang Transparansi Informasi Produk Bank dan Penggunaan Data Pribadi Nasabah. selain itu, Pasal 40 ayat (1) UU Perbankan mengemukakan bahwa bank wajib merahasiakan keterangan mengenai nasabah penyimpan dan simpanannya, kecuali dalam hal sebagaimana dimaksud dalam Pasal 41, 41 A, Pasal 42, Pasal 43, Pasal 44, dan Pasal 44 A UU Perbankan.

Pasal 9 ayat (1) PBI mengatur mengenai kewajiban bank untuk meminta persetujuan tertulis dari nasabah, ketika bank akan memberikan dan/atau menyebarluaskan data nasabahnya tersebut kepada pihak lain untuk tujuan komersial, kecuali hal lain sesuai dengan peraturan perundang-undangan. Tentunya dalam permintaan persetujuan tersebut, bank wajib menjelaskan tujuan dan konsekuensi dari pemberian dan atau penyebarluasan data pribadi nasabahnya kepada pihak lain sesuai dengan Pasal 9 (2) PBI 7/6/PBI/2005.

Bentuk pelaksanaan dari Pasal 9 PBI ini dituangkan dalam kaliamat yang berbunyi: Dengan menandatangani formulir ini :

a. Bank hanya akan menggunakan data pribadi saya selaku nasabah yang terdapat pada formulir aplikasi ini untuk kepentingan internal bank dan data pribadi nasabah tsb. Tidak akan diberikan dan atau disebarluaskan kepada pihak lauin diluar badan hukum bank, kecuali sebagaimana diatur pada ketentuan perundang-undangan yang berlaku.

b. Apabila di kemudian hari bank akan memberikan dan memyebarluaskan data pribadi saya selaku nasabah kepada pihak lain diluar badan hukum bank untuk tujuan komersial, maka bank akan meminta persetujuan tertulis terlebih dahulu dari saya (dokumen pernyataan akan saya buat dikemudian hari).

Pihak bank, dalam hal ini Customer Service, wajib mengarahkan calon nasabahnya untuk mengisi formulir data nasabah secara menyeluruh termasuk memberikan penjelasan mengenai persetujuan penggunaan data pribadi nasabah yang telah dicantumkan dalam formulir data nasabah tersebut. Persetujuan penggunaan data pribadi nasabah ini bersifat optout, dimana dengan tidak memberikan tanda centang pada klausula berarti nasabah memberikan persetujuan dan kuasa kepada bank untuk menggunakan semua data, keterangan dan informasi yang diperoleh bank mengenai nasabah untuk segala keperluan lainnya sepanjang dimungkinkan dan diperkenankan oleh perundang-undangan yang berlaku, termasuk yang bertujuan untuk pemasaran produk-produk bank ataupun produk pihak lain yang bekerjasama dengan bank.

Sesuai dengan Pasal $10 \mathrm{PBI}$, bank meminta persetujuan penggunaan data pribadi nasabah bank, baik sebelum maupun setelah nasabah melakukan transaksi yang berkaitan dengan produk bank. Penggunaan kebijakan 
pemberian data pribadi nasabah ini digunakan untuk keperluan internal bank dan atau secara khusus per kasus menggunakan data pribadi nasabah untuk keperluan pihak lain di luar badan hukum bank untuk tujuan komersial. Penggunaan data pribadi nasabah untuk tujuan komersial oleh pihak lain di luar badan hukum ini, bank berkewajiban untuk memiliki jaminan tertulis dari pihak lain tersebut sesuai dengan yang tercantum dalam Pasal 11 PBI.

\section{b. Perlindungan Hukum Represif}

Perlindungan hukum yang bersifat represif, yaitu perlindungan hukum yang dibuat untuk menyelesaikan suatu sengketa yang dapat menimbulkan suatu kerugian. Perlindungan ini tergolong dalam perlindungan langsung yang diberikan kepada nasabah penyimpan dana terhadap kemungkinan timbulnya resiko kerugian dari kegiatan usaha yang dilakukan oleh bank. Adanya ganti kerugian ini merupakan bentuk perlindungan represif secara perdata. Sementara itu, bentuk perlindungan represif secara pidana kepada pihak bank yang diwakili oleh anggota Dewan Komisaris, Direksi, pegawai bank atau Pihak Terafiliasi lainnya dapat dikenakan pidana penjara sekurang-kurangnya 2 (dua) tahun dan paling lama 4 (empat) tahun serta denda sekurang-kurangnya Rp.4.000.000.000,00 (empat miliar rupiah) dan paling banyak Rp.8.000.000.000,00 (delapan miliar rupiah). Hal ini diatur dalam Pasal 47 ayat (2) UU Perbankan "Anggota Dewan Komisaris, Direksi, pegawai bank atau Pihak Terafiliasi lainnya yang dengan sengaja memberikan keterangan yang wajib dirahasiakan menurut Pasal 40, diancam dengan pidana penjara sekurang-kurangnya 2 (dua) tahun dan paling lama 4 (empat) tahun serta denda sekurang-kurangnya Rp.4.000.000.000,00 (empat miliar rupiah) dan paling banyak Rp.8.000.000.000,00 (delapan miliar rupiah)"

Berdasarkan pembahasan di atas, maka dapat dinyatakan bahwa adanya sanksi ganti kerugian merupakan bentuk perlindungan reprensif secara perdata, sedangkan adanya sanksi pidana penjara paling sedikit 2 tahun dan paling lama 4 tahun serta denda paling sedikit Rp. 4 miliar dan paling banyak Rp. 8 miliar merupakan bentuk perlindungan reprensif secara pidana.

Pihak bank mempunyai tanggung jawab langsung apabila ada pengaduan yang diajukan oleh nasabahnya yang merasa kurang puas atau merasa dirugikan atas pelayanan perbankan. Pada dasarnya pihak bank mempunyai sistem pelayanan pengaduan nasabah termasuk mengenai layanan pengaduan nasabah terkait penggunaan data pribadi nasabah. Mengenai layanan pengaduan nasabah ini diatur dalam Peraturan Otoritas Jasa Keuangan Nomor 18/POJK.07/2018 tentang Layanan Pengaduan Konsumen di Sektor Jasa Keuangan (POJK No.18/POJK.07/2018). Pasal 1 angka 7 POJK No.18/POJK.07/2018 mendefinisikan layanan pengaduan adalah layanan yang disediakan oleh Pelaku Usaha Jasa Keuangan (PUJK) untuk mengupayakan penyelesaian Pengaduan di sektor jasa keuangan. Pengaduan konsumen ini termasuk pengaduan nasabah bank terkait adanya pelanggaran kerahasiaan bank oleh pihak bank. Selanjutnya fungsi atau unit Layanan Pengaduan diatur dalam Pasal 27 POJK No.18/POJK.07/2018 yang mengatur bahwa Layanan Pengaduan memiliki tugas paling sedikit: 
1) menerima, menangani dan menyelesaikan Pengaduan yang disampaikan oleh Konsumen dan/atau Perwakilan Konsumen;

2) menetapkan target kinerja, pemantauan, evaluasi, dan pelaporan kinerja terkait Layanan Pengaduan;

3) melaporkan kepada Direksi PUJK mengenai proses Layanan Pengaduan, serta memberikan rekomendasi untuk perbaikan dan pengembangan proses Layanan Pengaduan;

4) menyusun dan menyampaikan laporan Layanan Pengaduan kepada Otoritas Jasa Keuangan melalui Direksi PUJK;

5) menyusun materi penanganan Pengaduan yang akan dicantumkan dalam laporan tahunan, laman (website), dan/atau media lain yang dikelola secara resmi oleh PUJK; dan

6) menjadi penghubung penanganan Pengaduan yang disampaikan Konsumen dan/atau Perwakilan Konsumen kepada Otoritas Jasa Keuangan dan/atau otoritas lainnya. ${ }^{12}$

Tanggungjawab pihak bank sebagaimana diatur dalam Pasal 27 POJK No.18/POJK.07/2018 di atas diharapkan agar dapat lebih memperhatikan pengaduan nasabah terkait penggunaan data pribadi nasabah dengan baik.

\subsection{Problematika Pengungkapan Rahasia Bank antara Kepentingan Negara dan Perlindungan Kepada Nasabah}

Pada dasarnya kewajiban bank untuk menjaga rahasia bank sudah diikat dalam hukum perdata maupun pidana. Kewajiban perdata dikarenakan alasan pertama, bahwa hubungan antara nasabah dan bank merupakan fiduciary relation dan confidential relation, sehingga kepercayaan serta kerahasiaan hubungan keduanya merupakan moral obligation (kepatutan). Sedangkan yang kedua adalah dilihat pada ketentuan Pasal 1 angka 18 UU Perbankan yang pada intinya hubungan kerahasiaan bank adalah hubungan kontraktual antara bank dan nasabah debitur mengandung syarat yang tersirat (implied term) bahwa bank mempunyai kewajiban untuk merahasiakan keterangan mengenai nasabah debitur. Hal ini diperkuat dengan prinsip perjanjian yang diatur dalam Pasal 1339 Kitab Undang-Undang Hukum Perdata (selanjutnya disebut KUHPerdata) yang pada intinya mengatakan bahwa perjanjian tidak hanya mengikat untuk hal-hal yang dengan tegas dinyatakan dalamnya, tetapi juga untuk segala sesuatu yang menurut sifat persetujuannya diharuskan oleh kepatutaan, kebiasaan, atau undangundang. Sedangkan kewajiban menjaga kerahasiaan bank diatur dalam Pasal 40.

Rahasia bank di Indonesia tidak bersifat mutlak. Menurut teori rahasia bank yang bersifat nisbi atau relatif ini justru memberikan ruang bagi bank untuk membuka rahasia atau keterangan-keterangan mengenai nasabahnya apabila memang ada keadaan yang mendesak menuntut untuk itu, antara lain adalah untuk kepentingan negara. ${ }^{13} \mathrm{Hal}$ tersebut dapat ditemukan dalam ketentuan Pasal 40 ayat (1) UU Perbankan yang menyebutkan bahwa ketentuan rahasia bank penerapannnya dikecualikan dalam hal

\footnotetext{
12 Pasal 27 Peraturan Otoritas Jasa Keuangan Nomor 18/POJK.07/2018 tentang Layanan Pengaduan Konsumen di Sektor Jasa Keuangan

${ }^{13}$ Ghina Rossana, Penafsiran Pasal 40 Undang-Undang Nomor 10 Tahun 1998 Mengenai Kerahasiaan Bank, LamLaj, Volume 1, Nomor 2, 2016, Hlm.121.
} 
sebagaiamana di maksud Pasal 41, 41 A, 42, 43,Pasal 44 dan Pasal 44A UU Perbankan, kata "kecuali" diartikan sebagai pembatasan terhadap berlakunya rahasia bank. Mengenai keterangan yang disebutkan dalam pasal-pasal tadi bank boleh tidak merahasiakannya (boleh mengungkapkannya). ${ }^{14}$

Berdasarkan ketentuan Pasal 40 ayat (1) tersebut, bank tidak boleh merahasiakannya (boleh mengungkapkannya) dalam hal untuk kepentingan perpajakan (Pasal 41 ayat (1) UU Perbankan), untuk kepentingan perkara perdata (Pasal 43 UU Perbankan) dan untuk kepentingan tukar menukar informasi antar bank (Pasal 44 UU Perbankan) ${ }^{15}$ Terkait dengan tukar menukar informasi antar bank sebagaimana diterangkan di atas, kemudian berkembang tukar menukar antar bank tersebut tidak hanya melibatkan bank-bank dalam 1 (satu) negeri saja, tapi juga melibatkan bank antar negara. Organisation for Economic Co-operation and Developmen (OECD) kemudian menginisiasi program yang disebut Automatic Exchange of Information (AEoI). Program ini muncul dengan motif untuk mengurangi praktek penghindaran pajak atau transfer pricing yang tujuannya untuk menguntungkan satu pihak tertentu. Automatic Exchange of Information (AEOI) dipahami sebagai suatu kerjasama internasional di bidang pertukaran informasi untuk tujuan perpajakan, terutama untuk mencegah aktifitas penghindaran dan pengelakan pajak yang menjadi penyebab utama tergerusnya basis pemajakan di yurisdiksi dengan tarif rendah. AEoI mengemuka pada Tahun 2010, ketika Pemerintah Amerika mengeluarkan Foreign Account Tax Compliance Act (FATCA) yang mana mewajibkan lembaga keuangan yang berada di luar Amerika Serikat untuk melakukan pelaporan kepada pemerintah Amerika Serikat mengenai akun keuangan yang dimiliki oleh penduduk Amerika Serikat.16

Berkaitan dengan penerobosan rahasia bank sebagai dampak AEOI, bahwa penerapan AEOI memang akan memunculkan konsekuensi tidak adanya lagi kerahasiaan bank untuk kepentingan perpajakan. ${ }^{17}$ AEOI adalah program pertukaran informasi keuangan terkait pajak, dilakukan secara berkala, otomatis, dan menyeluruh (bulk). Informasi keuangan yang dikirim adalah milik warga asing yang menetap di satu negara dan dikirim kepada otoritas pajak negara asal warga tersebut. ${ }^{8}$ Dalam program ini, cakupan informasi yang dikirim sudah disepakati diawal, misalnya, bank di Swiss mengirim informasi keuangan warga Indonesia yang ada pada bank tersebut kepada lembaga pajak di Indonesia. Adanya AEOI akan sangat berguna bagi negara yang warganya banyak bekerja di luar negeri atau menyimpan kekayaan di luar negeri. Dengan sistem ini, wajib pajak didorong untuk memberi laporan kekayaan dengan benar. Jika tidak, maka AEOI akan menjadi salah satu bukti bagi negara untuk

${ }^{14}$ Rani Sri Agustina, Rahasia Bank, CV KENI Media, Bandung, 2017, hlm.131, Mengutip Abdulkadir Muhammad dan Rilda Murniati, Segi Hukum Lembaga Keuangan dan Pembiayaan, PT Citra Aditya Bakti, Bandung, 2004, Hlm. 79.

${ }^{15}$ Neni Sri Imaniyati dan Panji Adam Agus Putra, Pengantar Hukum Perbankan Indonesia, PT Refika Aditama, Bandung, 2016, Hlm. 210-212.

16 Masnur Tiurmaida Mallau, Aspek Hukum Peraturan Kebijakan Pemerintah Indonesia Menghadapi Liberalisasi Ekonomi Regional: Masyarakat Ekonomi ASEAN 2015, Jurnal Rechtsvinding, Vol. 3, No. 2, 2014, Hlm. 48.

${ }_{17}$ Marnia Rani, Perlindungan Otoritas Jasa Keuangan terhadap Kerahasiaan dan Keamanan Data Pribadi Nasabah Bank, Jurnal Selat, Vol. 2, No. 1, 2014, Hlm.31.

18 Vokhid Urinov, Developing Country Perspectives on Automatic Exchange of Tax Information, Law, Social Justice \& Global Development Journal (LGD), 2015, Hlm. 63. 
menjatuhkan denda serta sanksi terkait kebohongan laporan harta benda yang dibuat oleh warga negaranya.

AEoI dipahami sebagai cara yang melibatkan sistem dan transmisi berkala secara massal dari wajib pajak oleh negara tujuan terhadap negara asal yang meliputi beberapa kategori pendapatan (e.g deviden, keuntungan, royalty, gaji, pensiunan dan lain-lain. ${ }^{19}$ Informasi yang ditukar secara otomatis adalah informasi yang dikumpulkan di negara tujuan berdasarkan rutinitas dasar, meliputi pelaporan pembayaran oleh pembayar (lembaga keuangan, pengusaha dan lainnya).

Dengan demikian, secara sederhana AeoI adalah sistem yang mendukung pertukaran informasi rekening wajib pajak antar negara yang memungkinkan bagi para wajib pajak yang membuka rekening bank di negara lain dan akan langsung terlacak di negara asal sehingga nantinya suatu Negara dapat mengetahui warga negaranya yang merupakan wajib pajak membuka rekening di Negara lain dan mengetahui jika terdapat sebuah kemungkinan praktek transfer pricing dan praktek pencucian uang.

Pengungkapan rahasia bank untuk kepentingan Negara sebagaimana dikemukakan di atas menimbulkan opini publik bahwa seolah-olah rahasia bank sudah tidak relevan lagi keberadaannya. Di salah satu sisi pembukaan rahasia bank tersebut bertujuan untuk mencegah adanya penghindaran dan pengelakan pajak, namun di sisi lain Otoritas Jasa Keuangan (OJK) harus tetap melindungi kerahasiaan data nasabah yang merupakan bagian dari hak nasabah harus tetap dilindungi.

Menurut OJK adanya kekhawatiran menabrak Pasal kerahasiaan bank sebenarnya tidak beralasan karena ketika nasabah bersedia untuk memberikan kuasa membuka rekeningnya maka pasal kerahasian bank menjadi tidak berlaku. Demikian pula ketakutan adanya pelarian dana ke luar negeri tidak relevan lagi karena negara tujuan pelarian dana tersebut sebagian besar juga telah berkomitmen untuk saling memberikan informasi perbankan secara otomatis.

Berdasarkan pemaparan tersebut di atas, bahwa yang menjadi problematika dalam pelaksanaan AEOI dengan terbitnya Peraturan OJK Nomor 25/POJK.03/2015 tentang Penyampaian Informasi Nasabah Asing terkait Perpajakan kepada Negara Mitra atau Yurisdiksi Mitra adalah terkait pengaturan rahasia bank. Isi dari POJK ini sebagai wujud sinkronisasi hukum dalam mewadahi dilaksanakannya Automatic Exchange of Information (AEOI). AEOI merupakan tindak lanjut dari Penandatanganan Multilateral Competent Authority Agreement (MCAA) oleh Meneteri Keuangan Republik Indonesia yang mana merupakan salah satu bentuk komitmen Pemerintah Indonesia dalam upaya meningkatkan akses data pihak ketiga, khususnya data perbankan untuk kepentingan perpajakan. Dalam hal ini apakah ketentuan rahasia bank tersebut harus dihapuskan sehingga tidak legitimate atau tidak ada lagi ketentuan mengenai rahasia bank, ataukah ketentuan mengenai rahasia bank ini tetap legitimate namun perlu ada pengaturan khusus yang mengaturnya sehingga pelaksanaan pertukaran informasi secara otomatis (AEOI) akan benar-benar siap dilaksanakan pada tahun 2018 dan memiliki legitimasi hukum yang jelas.

Legitimasi hukum merupakan pengakuan hukum di mata masyarakat serta merupakan bagian dari suatu tindakan perbuatan hukum yang berlaku dan juga perundang-undangan yang sah, di mana hal ini mencakup peraturan hukum formal,

19 Organisation for Economis Co-Operation and Development, Standard for AutomaticExchange of Financial Account Information : Common Reporting Standard, OECD, 2014, Hlm. 7. 
hukum etnis, hukum adat istiadat, maupun hukum kemasyarakatan yang terdapat di dalam masyarakat itu sendiri dan diakui secara sah, sehingga legitimasi dianggap sangat penting di dalam kehidupan masyarakat luas. Perubahan nilai dan norma sosial dalam masyarakat sebagai konsekuensi perkembangan peradaban manusia merupakan salah satu contoh yang melatarbelakangi pergeseran dari legitimasi.

Dalam rangka mengatasi problematika legitimasi hukum rahasia perbankan pasca berlakunya Peraturan OJK Nomor 25/POJK.03/2015 tentang Penyampaian Informasi Nasabah Asing terkait Perpajakan kepada Negara Mitra atau Yurisdiksi Mitra. Isi dari POJK ini adalah mengatur penerapan perjanjian Pertukaran Informasi secara Otomatis, LJK wajib menyampaikan laporan kepada otoritas pajak Indonesia berupa informasi Nasabah Asing terkait perpajakan untuk diteruskan kepada otoritas pajak Negara Mitra atau Yurisdiksi Mitra. Laporan ini merupakan laporan mengenai informasi Nasabah Asing yang memiliki saldo rekening atau nilai rekening paling sedikit sesuai dengan perjanjian Pertukaran Informasi secara Otomatis.

Lebih lanjut, Pertukaran Informasi secara Otomatis yaitu pertukaran informasi keuangan nasabah LJK yang merupakan wajib pajak Negara Mitra atau Yurisdiksi Mitra yang berada di Indonesia untuk disampaikan kepada otoritas pajak Negara Mitra atau Yurisdiksi Mitra dimaksud, dan dapat berlaku sebaliknya bagi wajib pajak Indonesia yang merupakan nasabah LJK di Negara Mitra atau Yurisdiksi Mitra yang akan disampaikan informasi keuangannya kepada Otoritas Pajak di Indonesia. Dengan demikian inti dari Peraturan OJK Nomor 25/POJK.03/2015 tersebut di atas untuk melaksanakan pertukaran informasi secara otomatis di bidang perpajakan (AEOI), OJK melakukan langkah progresif untuk mengatasi kendala hukum tersebut. OJK menyiapkan sejumlah peraturan di sektor jasa keuangan untuk mendukung pelaksanaan AEOI yang akan mulai diimplementasikan pada September 2018. Salah satu wujud dari dukungan tersebut adalah dengan menyiapkan peraturan bagi lembaga jasa keuangan agar dapat menyampaikan data nasabah untuk dipertukarkan informasinya dalam rangka pajak dengan negara mitra atau yurisdiksi mitra. Terkait dengan ketentuan dalam Pasal 1 angka 28 dan Pasal 40 ayat (1) UU Perbankan yang mengatur kerahasiaan bank, OJK berniat untuk menyelesaikan kendala tersebut. Dalam hal ini akan dilakukan revisi atas ketentuan dalam UU Perbankan yang saat ini sudah masuk dalam salah satu program legislasi di DPR.

Di dalam Pasal 2 Peraturan OJK Nomor 25/POJK.03/2015 tentang Penyampaian Informasi Nasabah Asing terkait Perpajakan kepada Negara Mitra atau Yurisdiksi Mitra disebutkan bahwa informasi nasabah yang dipertukarkan secara otomatis untuk kepentingan perpajakan paling sedikit meliputi informasi nasabah dan informasi keuangan nasabah. Dari rumusan Pasal tersebut telah mengacu dan memenuhi rumusan pengertian rahasia bank yang termuat dalam Undang-Undang Perbankan beserta penafsiran resminya sebagaimana termuat dalam Surat Edaran Bank Indonesia.

Adanya kekhawatiran menabrak Pasal kerahasiaan bank yang menimbulkan problematika pengungkapan rahasia bank antara kepentingan negara dan perlindungan kepada nasabah sebenarnya tidak beralasan karena ketika nasabah bersedia untuk memberikan kuasa membuka rekeningnya maka pasal kerahasian bank menjadi tidak berlaku. Demikian pula ketakutan adanya pelarian dana ke luar negeri tidak relevan lagi karena negara tujuan pelarian dana tersebut sebagian besar juga telah berkomitmen untuk saling memberikan informasi perbankan secara otomatis. Berkaitan dengan penerobosan rahasia bank sebagai dampak AEOI, bahwa penerapan AEOI memang 
akan memunculkan konsekuensi tidak adanya lagi kerahasiaan bank untuk kepentingan perpajakan.

Hal yang menimbulkan problematika dalam pelaksanaan AEOI dengan terbitnya Peraturan OJK Nomor adalah terkait pengaturan rahasia bank. Dalam hal ini apakah ketentuan rahasia bank tersebut harus dihapuskan sehingga tidak legitimate atau tidak ada lagi ketentuan mengenai rahasia bank, ataukah ketentuan mengenai rahasia bank ini tetap legitimate namun perlu ada pengaturan khusus yang mengaturnya sehingga pelaksanaan pertukaran informasi secara otomatis (AEOI) akan benar-benar siap dilaksanakan pada tahun 2018 dan memiliki legitimasi hukum yang jelas.

OJK dan Dirjen Pajak menandatangani Nota Kesepahaman tentang Kerja Sama dalam Bidang Pengaturan, Pengawasan dan Penegakan Hukum serta Perlindungan Konsumen di Sektor Jasa Keuangan yang ruang lingkupnya meliputi Penerapan Pembukaan Rahasia Nasabah Bank. Sebagai salah satu bentuk pelaksanaan Nota Kesepahaman tersebut, diresmikan peluncuran bersama sistem izin pembukaan rahasia nasabah penyimpan untuk tujuan perpajakan. Sistem ini terdiri dari dua aplikasi yaitu Aplikasi Usulan Buka Rahasia Bank (AKASIA) bagi internal Kementerian Keuangan dan Aplikasi Buka Rahasia Bank (AKRAB) bagi internal OJK.

Pasca berlakunya Peraturan OJK No. 25/POJK.03/2015 tentang Penyampaian Informasi Nasabah Asing Terkait Perpajakan Kepada Negara Mitra Atau Yurisdiksi Mitra, seperti yang telah dijelaskan dalam pembahasan sebelumnya bahwa ketentuan rahasia bank masih legitimate namun ada pengaturan lebih lanjut yang telah disediakan baik oleh OJK maupun Kementerian Keuangan dalam membuka rahasia bank untuk kepentingan pertukaran informasi secara otomatis di bidang perpajakan (AEOI).

Dalam Pasal 4 huruf c Undang-Undang Nomor 21 Tahun 2011 tentang Otoritas Jasa Keuangan menyatakan bahwa salah satu tujuan dibentuknya OJK adalah agar dapat melindungi kepentingan Konsumen dan masyarakat dalam di sektor jasa keuangan. Perlindungan ini dimaksudkan agar dapat memberikan rasa aman terhadap konsumen sebagai pengguna jasa keuangan.

Nasabah bank sebagai konsumen pengguna jasa perbankan, memiliki hak untuk mendapatkan perlindungan atas data pribadi yang ada pada bank tempat mereka menyimpan dana. Hubungan kontraktual antara bank dan nasabah sebagai konsumen pengguna jasa perbankan dalam penyimpanan dana, berakibat hukum bahwa bank harus melindungi kepentingan nasabah.

OJK sebagai lembaga pengawas di sektor jasa keuangan sangat melindungi hakhak setiap nasabah setiap lembaga jasa keuangan.Sebenarnya perlindungan OJK terhadap kerahasiaan bank sudah dilaksanakan sebelum Indonesia meratifikasi MCAA untuk melaksanakan AEOI. Jika AEOI pada tahun 2018 nanti mulai diterapkan, maka OJK menjadi garda terdepan dalam mengawasi pelaksanaan pembukaan rahasia bank melalui Aplikasi Usulan Buka Rahasia Bank (AKASIA) bagi internal Kementerian Keuangan dan Aplikasi Buka Rahasia Bank (AKRAB) bagi internal OJK supaya tidak terjadi penyelewengan dan penyalahgunaan.

Kerahasiaan bank merupakan hal mendasar yang dibutuhkan dalam setiap sistem perbankan yang sehat. Hal ini berawal dari hubungan antara bank dan nasabahnya yang mewajibkan bank tersebut untuk merahasiakan semua informasi yang dimiliki oleh nasabahnya. Oleh karena seorang nasabah tidak mungkin mempercayakan dana serta urusan keuangan mereka pada bank apabila lembaga tersebut tidak 
menjamin kerahasiaan data-data yang dimiliki oleh nasabah tersebut. Untuk itu, sistem ini memainkan peranan penting dalam melindungi kerahasiaan perbankan yang dimiliki oleh suatu individu atau entitas tertentu.

Rahasia bank atau bank secrecy dilaksanakan dimanapun di dunia ini, hal ini berarti setiap lembaga keuangan bank mempunyai rahasia bank. Rahasia bank merupakan prinsip etis yang umum dan hampir semua negara mempunyai peraturan hukum yang mengatur rahasia bank. Relasi antara nasabah dan bank merupakan relasi kepercayaan. Bank tentu tidak berlaku etis bila memberitahu kepada pihak lain tentang kekayaan seseorang atau badan hukum yang dititipkan kepadanya. Kewajiban menjaga rahasia bank tersebut tentunya mengenal batas, karena kepentingan banyak nasabah yang harus diperhatikan.

Kerahasiaan bank dapat berpotensi menimbulkan kegiatan menyembunyikan penghasilan secara ilegal untuk menghindari kewajiban membayar pajak.Untuk menanggulanginya, pihak otoritas pajak memerlukan akses untuk mnganalisis catatan transaksi keuangan wajib pajak agar dapat mendeteksi celah-celah kebocoran pajak dan melakukan upaya penegakan hukum.

Sebelum Indonesia meratifikasi MCAA untuk melaksanakan AEOI, dalam rangka memberikan perlindungan terhadap rahasia bank, OJK telah menerbitkan Peraturan OJK untuk melindungi konsumen di sektor jasa keuangan. Menerbitkan Peraturan OJK Nomor 1/POJK.07/2013 Tahun 2013 tentang Perlindungan Konsumen Sektor Jasa Keuangan dan Surat Edaran OJK Nomor 14/SEOJK.07/2014 tentang Kerahasiaan dan Keamanan Data dan/ atau Informasi Pribadi Konsumen.

Terkait dengan sampai batas mana OJK melindungi rahasia bank, bahwa OJK melindungi ketentuan rahasia bank sampai pada batas yang ditentukan oleh UndangUndang, karena dalam hal ini OJK tidak boleh bertindak di luar kewenangan yang diberikan Undang-Undang. OJK tetap menjaga komitmennya sebagai lembaga pengawas sektor jasa keuangan yaitu mengatur, mengawasi, dan melindungi namun tetap pada batas kewenangannya sesuai yang diamanatkan dalam Undang-Undang.

\subsection{Hak Tolak Bank untuk Membuka Rahasia Bank}

Hubungan hukum antara nasabah dengan bank didasarkan pada dua sumber hukum, yaitu perjanjian penyimpanan (penempatan) dana dan peraturan perundangundangan perbankan. Hubungan hukum yang bersumber pada perjanjian penyimpanan dana merupakan aspek perdata murni yang didasarkan pada asas kebebasan berkontrak sebagaimana diatur dalam buku III KUHPerdata. Prinsip kerahasiaan bank adalah suatu prinsip yang mengharuskan atau mewajibkan bank untuk merahasiakan segala sesuatu yang berhubungan nasabah penyimpan yang sudah merupakan kelaziman dalam dunia perbankan (wajib) dirahasiakan. ${ }^{20}$

Adanya kewajiban untuk merahasiakan (duty of confidentiality), hal tersebut dianggap sudah tercantum secara implisit dalam hubungan kontraktual antara bank dengan nasabah, sehingga bank tetap berkewajiban untuk merahasiakan keterangan tentang nasabahnya, bahkan hal ini juga berlaku bagi mantan nasabah. Duty of confidentiality ini terdiri dari:

${ }^{20}$ Djoni S. Gazali dan Rachmadi Usman, Hukum Perbankan, Sinar Grafika, Jakarta, 2010, Hlm. 30. 
a. Kewajiban untuk tidak memberikan informasi tentang nasabahnya kepada pihak ketiga.

b. Kewajiban untuk tidak menggunakan informasi rahasia yang diperoleh dari nasabahnya untuk kepentingannya, untuk menghindari adanya conflictof interest bagi bank. ${ }^{21}$

Kewajiban bank untuk merahasiakan mengenai nasabah penyimpan dan simpanannya dapat dituangkan secara eksplisit atau implisit dalam kontrak yang dibuat oleh pihak dan nasabah. Hal ini berarti, meskipun kewajiban merahasiakan tidak dicantumkan secara eksplisit dalam kontrak, tidak menjadikan bank terlepas dari ketentuan merahasiakan, karena dalam melaksanakan suatu perjanjian, harus didasarkan pada asas itikad baik antara pihak-pihak.

Prinsip kerahasiaan bank yang mewajibkan bank untuk merahasiakan segala sesuatu tentang nasabah penyimpan dan simpanannya, bertujuan untuk melindungi kepentingan nasabah secara individual. Rahasia bank dalam hal ini diperlukan karena adanya keyakinan bahwa dengan rahasia bank, maka bank dapat dipercaya oleh masyarakat yang akan menyimpan uangnya di bank. Rahasia bank inilah yang menjadi sebab, mengapa bank dapat menjadi lembaga kepercayaan. Untuk orang yang menghendaki suasana non-disclosure, kebutuhan untuk memegang teguh rahasia bank adalah untuk membuat debitur merasa confidence bahwa dana yang disimpannya di bank akan aman terhindar dari penyalahgunaan pihak-pihak tertentu yang ingin mencari informasi tentang keadaan keuangan nasabah dengan cara tidak dibenarkan oleh aturan yang ada. ${ }^{22}$

Berdasarkan uraian di atas dapat dinyatakan bahwa bank berhak menolak untuk membuka rahasia bank berdasarkan hubungan kontraktual antara bank dengan nasabahnya. Menurut Pasal 1338 KUHPerdata perjanjian mengikat bagi para pihak yang membuatnya, tetapi tidak mengikat bagi pihak ketiga dalam hal ini termasuk negara sebagai pihak ketiga. Ketentuan ini berarti bahwa perjanjian hanya mengikat bagi para pihak yang membuatnya saja. Perjanjian tidak mempunyai kekuatan mengingat bagi pihak ketiga yaitu pihak yang berada di luar para pihak yang membuat perjanjian. Mengingat negara juga merupakan pihak yang berada di luar para pihak yang membuat perjanjian, maka perjanjian yang dibuat oleh para pihak itu tidak mengikat bagi negara, sebaliknya negara juga tidak bisa ikut campur terhadap perjanjian yang dibuat secara sah.

\section{Kesimpulan}

Berdasarkan hasil penelitian dan pembahasan yang telah dikemukakan di atas, maka dapat disimpulkan hal-hal sebagai berikut:

1. Penerapan rahasia bank sebagai bentuk perlindungan hukum kepada nasabah terdiri dari perlindungan hukum preventif dan represif. Perlindungan hukum preventif yang secara tidak langsung diberikan yaitu dalam bentuk penjelasan atau informasi lisan dari pihak bank mengenai penggunaan data pribadi nasabah melalui klausula yang tercantum dalam formulir data nasabah. Sedangkan perlindungan hukum represif dilakukan dengan menjatuhkan sanksi ganti kerugian yang merupakan bentuk perlindungan reprensif secara perdata, sementara itu adanya

21 Yunus Husein, Op. cit., Hlm.60.

22 Yunus Husein, Op. cit., Hlm. 38-49. 
sanksi pidana penjara paling sedikit 2 tahun dan paling lama 4 tahun serta denda paling sedikit Rp. 4 miliar dan paling banyak Rp. 8 miliar merupakan bentuk perlindungan reprensif secara pidana.

2. Problematika pengungkapan rahasia bank antara kepentingan negara dan perlindungan kepada nasabah harus dilakukan secara seimbang agar tidak timbul opini publik bahwa seolah-olah rahasia bank sudah tidak relevan lagi keberadaannya. Di salah satu sisi pembukaan rahasia bank tersebut bertujuan untuk mencegah adanya penghindaran dan pengelakan pajak, namun di sisi lain Otoritas Jasa Keuangan (OJK) harus tetap melindungi kerahasiaan data nasabah yang merupakan bagian dari hak nasabah harus tetap dilindungi. Upaya Otoritas Jasa Keuangan dalam memberikan perlindungan hukum terhadap rahasia perbankan pasca dikeluarkannya Peraturan OJK Nomor 25/POJK.03/2015 pada prinsipnya tetap mengacu pada peraturan perundang-undangan yang berlaku. Perihal sampai batas mana OJK melindungi rahasia bank, bahwa OJK memberikan perlindungan terhadap rahasia bank sampai batas yang ditentukan oleh Undang-Undang, karena dalam hal ini OJK tidak boleh bertindak di luar kewenangan yang diberikan Undang-Undang

3. Hak tolak bank untuk membuka rahasia bank menunjukkan bahwa bank berhak menolak untuk membuka rahasia bank berdasarkan hubungan kontraktual antara bank dengan nasabahnya. Menurut Pasal 1338 KUHPerdata perjanjian mengikat bagi para pihak yang membuatnya, tetapi tidak mengikat bagi pihak ketiga dalam hal ini termasuk negara sebagai pihak ketiga.

\section{Saran} berikut :

Adapun saran-saran yang dapat dikemukakan oleh Penulis adalah sebagai

1. Para pihak yang berkaitan dengan pembukaan rahasia bank meskipun untuk kepentingan negara disarankan untuk memegang teguh prinsip kehati-hatian bank dalam pelaksanaan pembukaan rahasia bank dengan tujuan menjaga kepercayaan masyarakat kepada perbankan.

2. Disarankan adanya rumusan yang lebih jelas, tegas dan terperinci dalam Peraturan Bank Indonesia Nomor 2/19/PBI/2000 tentang Persyaratan Dan Tata Cara Pemberian Perintah Atas Izin Tertulis Membuka Rahasia Bank khususnya mengenai permintaan dari instansi pemerintah/negara kepada Bank Indonesia, hal ini dikarenakan sebagai sebuah peraturan pelaksana seharusnya peraturan tersebut lebih bersifat detail dan terperinci sehingga bank didalam menjalankan peraturan tersebut tidak ada keraguan dan kerancuan.

3. Mengingat pengaturan rahasia bank yang selama ini ada hanya untuk nasabah penyimpanan dana (kreditur), sehingga kedepannya disarankan untuk dibuat suatu ketentuan yang melindungi nasabah debitur, karena berjalannya sebuah kegiatan perbankan tidak terlepas juga dengan keberadaan nasabah debitur selaku pihak yang membutuhkan dana segar untuk menjalankan usahanya. Dengan adanya bentuk perlindungan hukum yang jelas, yang berupa sebuah peraturan yang mengatur perlindungan hukum bagi nasabah debitur, maka diharapkan akan membuka peluang usaha lebih kondusif dan nyaman karena akan senantiasa mendapatkan jaminan perlindungan yang maksimal bagi nasabah debitur, sehingga kegiatan perbankan kita bisa berjalan dengan baik dan lancar. 


\section{Daftar Pustaka}

\section{Buku :}

Agustina, Rani Sri, Rahasia Bank, CV KENI Media, Bandung, 2017.

Fuady, Munir, Hukum Perbankan Modern, Edisi Revisi, PT. Citra Aditya Bakti, Bandung, 2009.

Gazali, Djoni S. dan Usman, Rachmadi, Hukum Perbankan, Sinar Grafika, Jakarta, 2010.

Husein, Yunus, Rahasia Bank dan Penegakan Hukum, Pustaka Juanda Tigalima, Jakarta, 2010.

Imaniyati, Neni Sri dan Putra, Panji Adam Agus, Pengantar Hukum Perbankan Indonesia, PT Refika Aditama, Bandung, 2016.

Muhammad, Abdulkadir dan Murniati, Rilda, Segi Hukum Lembaga Keuangan dan Pembiayaan, PT Citra Aditya Bakti, Bandung, 2004.

Organisation for Economis Co-Operation and Development, Standard for AutomaticExchange of Financial Account Information : Common Reporting Standard, OECD, 2014.

Soekanto, Soerjono, Pengantar Penelitian Hukum, Universitas Indonesia Press, Jakarta, 2012.

Soemitro, Ronny Hanitijo, Metode Penelitian Hukum dan Jurumetri, Ghalia Indonesia, Jakarta, 2010.

Waluyo, Bambang, Penelitian Hukum Dalam Praktik, Penerbit Sinar Grafika, Jakarta, 2011.

\section{Makalah/Jurnal:}

Christian, John Bert, Bismar Nasution dan Suhaidi, Mahmul Siregar, "Analisis Hukum Atas Penerapan Rahasia Bank di Indonesia Terkait dengan Perlindungan Data Nasabah Berdasarkan Prinsip Kepercayaan Kepada Bank", USU Law Journal, Vol.4, No.4, 2016.

Mallau, Masnur Tiurmaida, "Aspek Hukum Peraturan Kebijakan Pemerintah Indonesia Menghadapi Liberalisasi Ekonomi Regional: Masyarakat Ekonomi ASEAN 2015”, Jurnal Rechtsvinding, Vol. 3, No. 2, 2014.

Manurung, Tumpak Hasiholan, Maryati Bachtiar dan Dasrol, “Analisis Yuridis Mengenai Bentuk Perlindungan Rahasia Bank dan Sanksi terhadap Pelanggaran Rahasia Bank", JOM Fakultas Hukum, Volume II, Nomor 2, 2015.

Murwadji, Tarsisius, "Antisipasi Pelarian Dana Asing ke Luar Negeri Melalui Perlindungan Kontraktual Pembukaan Rahasia Bank”, Padjadjaran Jurnal Ilmu Hukum, Vol. 2, No. 2, 2015.

Rani, Marnia, “Perlindungan Otoritas Jasa Keuangan terhadap Kerahasiaan dan Keamanan Data Pribadi Nasabah Bank", Jurnal Selat, Vol. 2, No. 1, 2014. 
Rossana, Ghina, “Penafsiran Pasal 40 Undang-Undang Nomor 10 Tahun 1998 Mengenai Kerahasiaan Bank", LamLaj, Volume 1, Nomor 2, 2016.

Singson, Gabriel C., "Law and Jurisprudence on Secrecy of Bank Deposits”, Ateneo Law Journal, Vol. 46, 2001.

Sutiawan, Hendrik Agus, Etty Mulyati dan Ijud Tajudin, "Perlindungan Nasabah Terkait Praktik Pembukaan Rahasia Bank oleh Pegawai Bank dalam Proses Penegakan Hukum Tindak Pidana Pencucian Uang Dihubungkan dengan Asas Kepastian Hukum", Jurnal Hukum \& Pembangunan, Vol.48, No.3, 2018.

Urinov, Vokhid, "Developing Country Perspectives on Automatic Exchange of Tax Information”, Law, Social Justice \& Global Development Journal (LGD), 2015.

\section{Peraturan Perundang-Undangan:}

Kitab Undang-Undang Hukum Perdata.

Undang-Undang Nomor 8 Tahun 1981 tentang Hukum Acara Pidana.

Undang-Undang Nomor 10 Tahun 1998 tentang Perubahan Atas Undang-Undang Nomor 7 Tahun 1992 tentang Perbankan.

Undang-Undang Nomor 21 Tahun 2011 tentang Otoritas Jasa Keuangan

Peraturan Bank Indonesia Nomor 2/19/PBI/2000 tentang Persyaratan dan Tata Cara Pemberian Perintah Atas Izin Tertulis Membuka Rahasia Bank.

Peraturan Bank Indonesia Nomor 7/6/PBI/2005 tentang Transparansi Informasi Produk Bank dan Penggunaan Data Pribadi Nasabah.

Peraturan Otoritas Jasa Keuangan Nomor 18/POJK.07/2018 tentang Layanan Pengaduan Konsumen di Sektor Jasa Keuangan

Peraturan Otoritas Jasa Keuangan Nomor 25/POJK.03/2015 tentang Penyampaian Informasi Nasabah Asing terkait Perpajakan kepada Negara Mitra atau Yurisdiksi Mitra 